\title{
A STUDY ON EMOTIONAL INTELLIGENCE OF HIGHER SECONDARY STUDENTS IN KARAIKUDI
}

\author{
Dr. C.S. Edhayavarman \\ Assistant Professor, Department of Business Administration, \\ Arumugam Pillai Seethai Ammal College, Tirupattur, Tamilnadu, India \\ P. Sivasankari \\ Assistant Professor, Department of Business Administration, \\ Arumugam Pillai Seethai Ammal College, Tirupattur, Tamilnadu, India
}

\begin{abstract}
The present study was conducted to investigate the emotional intelligence of higher secondary students in relation to community and parental education. The study was conducted on a random sample of 300 students studying in and Karaikudi. Emotional intelligence scale constructed and standardized by Balasubramanian(2003), has been used to measure emotional intelligence. It has been constructed based on the theory propounded by Daniel Goleman. The result of the study reveals that the higher secondary students have high level of emotional intelligence.
\end{abstract}

Key words: Emotional intelligence, higher secondary.

Cite this Article: C.S. Edhayavarman and P. Sivasankari, A Study on Emotional Intelligence of Higher Secondary Students in Karaikudi, International Journal of Management, 11(12), 2020, pp 2838-2847.

http://iaeme.com/Home/issue/IJM?Volume=11\&Issue=12

\section{INTRODUCTION}

In the new millennium, the students are challenged to learn at a higher level, to meet the demands of the competitive society. The rapid development of the era is challenging the adolescents to face the wave of globalization. Thus, the ability to control the emotions has become important for not carried away by the flow of negative and evil elements.

According to Elias (1997), "Emotional competence is the ability to understand, manage and express the emotional aspect of one's life in ways that enable the successful management of tasks such as learning, forming relationships, solving everyday problems and adopting to the complex demands of growth and development".

Therefore, cognitive abilities alone are not responsible for ensuring peaceful and successful life. But the peaceful school life of students and the successful learning in school is indirect 
need of emotional intelligence, which is the ability to monitor fellow students and that of the students feelings and emotions, to discriminate among them and form it one is able to guide one's own thinking and action.

The essential function of, "Emotional intelligence allows us to think more creatively and use our emotions to solve problems. The emotionally intelligent person is skilled in : Identifying emotions and regulating emotions." (Mayer and Salovey 1993)

A high emotional intelligence helps to maintain a state of harmony in oneself and finally be more self confident in dealing with the challenges of living and learning in educational institutions.

\subsection{Meaning of Education}

Education means the modification of behavior. Education is an activity or a process, which transforms the behavior of a person from "instinctive behavior" to "human behavior". Education involves both teaching and learning. Sometimes people learn by teaching themselves. Parents are a child's first perhaps most important teachers. They teach their children attitudes, habits and values that help to shape their character and remain with them throughout life.

\subsection{Importance of Education}

Education is a systematic process through which a child or an adult acquires knowledge, experience, skill and sound attitude. It makes an individual civilized, refined, cultured and educated. Education has been described as a process of waking up to life. Education in the broadest sense of the term is meant to aid the human being in his/her pursuit of wholeness. Wholeness implies the harmonious development of all the potentialities that the God has given to a person. True education is the harmonious development of the physical, mental, moral, spiritual and social values.

Education is essential for everyone. It is the level of education that helps people earns respect and recognition. Education is an indispensable part of life both personally and socially.

Students represent the society's investment for future. Their mental health and well-being are important not only in its own right but also as a factor contributing to the larger interest of the society.

\subsection{Emotion}

Emotion is a state of consciousness having to do with the arousal of feelings, distinguished from other mental states, as cognition, volition, and awareness of physical sensation.

Emotion is a mental state that arises spontaneously rather than through conscious effort and is after accompanied by psychological changes, ie the emotions of joy, sorrow and anger.

According to Crow and Crow (1973) "Emotion is an effective experience that accompanies generalized inner adjustment and mental and psychological stirred up status in an individual and that shows itself in his own behavior".

The quality of emotion is provided by the person's interpretation of its cause, the specific emotion that is felt depending on the person's interpretation and explanation.

\subsection{Intelligence}

Intelligence is defined as general cognitive problem solving skills. A mental ability involved in reasoning, perceiving relationships and analogies, calculating and learning quickly etc.

"Intelligence is a hypothetical idea which we have defined as being reflected by certain types of behavior". 
Individuals differ from one another in their ability to understand complex ideas, to adapt effectively to the environment, to learn from experience to engage in various forms of reasoning to overcome obstacles by taking thought.

Intelligence involves the ability to think, solve problems, analysis situations and understand Social values, Customs and Norms. Two main forms of intelligence are involved in most intelligence assessments.

\subsection{Emotional Intelligence}

Emotional intelligence is an integrated part of an individual's personality development. Salvoey and Mayer (1990) coined the term emotional intelligence and described it as a "form of social intelligence that involves the ability to monitor one's own and other feelings and emotions to discriminate among them and the use this information to guide one's thinking and action".

Goleman (1998) describes emotional intelligence as "the capacity for recognizing our own feelings and those of others for motivating ourselves and in our relationships".

\subsection{Concept of Emotional Intelligence}

It is the popular psychological concept that has captured the imagination of educationalists. Emotional intelligence was classified into four groups of competencies. They are,

- The ability to perceive, appraise and express accurately,

- The ability to access and evoke emotion when they facilitate cognition

- The ability to comprehend emotional message and to make use of emotional information and

- The ability to regulate one's own emotions to promote growth and well being. (salvoes peter and Mayor john, 1990)

\section{NEED AND SIGNIGICANCE OF THE STUDY}

Research is brain-based learning suggests that emotional health is fundamental to effective learning. According to a report from the National Centre for Clinical Infant Programs, the most critical element for a student's success in school is an understanding of how to learn that is emotional intelligence. Basically, a student who learns to learn is much more apt to succeed.

In School life, students feel difficult to control their emotions in order to face various situations. It is imperative to manage the stress and strain to keep pace with the demands of the World. Success in academics can be predicted more by emotional measures. Parent and teachers focus always on Academic performance through nurturing intelligence and they give less importance to their emotions. Emotions of a student can affect him in many ways. Intelligence may help students in acquiring subject knowledge but only emotional intelligence can enrich their learning proficiency and make them efficient as well as achievers. Hence the present study has been undertaken to study the emotional intelligence and academic achievement of higher secondary school students.।

\section{SCOPE OF THE STUDY}

The study investigates the phenomena related to emotional intelligence among higher secondary students in government and private educational institutions in and around Karaikudi from an academic point of view. It identifies the level of Emotional Intelligence based on Gender, Educational level. The study provided a foundation in exploring the impact of emotional intelligence of students in Personal, Academic and Career success which will further 
help the institutions to create best ideas and draw suitable plans to increase the level of emotional intelligence of their students.

\section{OBJECTIVES OF THE STUDY}

\subsection{Major objectives}

1. To find out the level of emotional intelligence of the higher secondary school students.

\subsection{Specific Objectives}

To find out the significant difference, if any, between emotional intelligence of higher secondary school students in relation to following variables such as

(a) Gender

(b) Locality of the School

(c) Residence of the Students

(d) Type of the Schools

(e) Nature of the School

(f) Parent's Occupation

2. To give suggestions to promote emotional intelligence among higher secondary school students.

\section{HYPOTHESES OF THE STUDY}

\section{Major Hypotheses}

The level of emotional intelligence of higher secondary school students is high.

\section{Specific Hypotheses}

- There exists no significant difference between male and female higher secondary school students in relation to their emotional intelligence.

- There is no significant difference among government, aided and private school students in relation to their emotional intelligence.

- There exists no significant difference between mean scores of emotional intelligence of higher secondary students with relation to locality of the schools.

- There exists no significant difference in relation to residence of the students with respect to emotional intelligence.

- There exists significant difference in relation to nature of the school with respect to emotional intelligence.

- There exists significant difference in relation to parents' occupation with respect to emotional intelligence.

- There exists significant difference in relation to type of school with respect to emotional intelligence.

\section{METHODOLOGY OF THE STUDY}

In this study normative survey method is adopted to investigate the existing emotional intelligence level of the higher secondary students studying in and around Karaikudi. This is five points rating scale and the items given in the research tool was verified with the help of guide and subject experts. The tool was administered to the sample selected in and around 
Karaikudi. Data were collected from various school students, analyzed by adopting appropriate statistical techniques for finding the emotional intelligence of higher secondary students.

\section{a) Population of the Study}

Population is defined as a well defined set of people living with common characteristics; population of the present study is the XI standard students of various higher secondary schools in and around Karaikudi.

\section{b) Research Tool}

In this study, the researcher employed the emotional intelligence questionnaire to collect data from students' respondents about the emotional intelligence of higher secondary students studying in and around Karaikudi.

\section{c) Statistical Techniques USED IN THIS STUDY}

In the present study the following statistical techniques are used.

- Mean

- Standard Deviation

- ' $t$ '-test was employed to find out the difference between mean scores of variables and

Pearson's product moment correlation method to find out the correlation between the mean scores of variables.

\section{ANALYSIS AND INTERPRETATION OF THE DATA}

\subsection{Testing of Hypotheses}

\section{Hypothesis : 1}

The higher secondary students have high level of emotional intelligence.

Table 1 The level of emotional intelligence of higher secondary school students

\begin{tabular}{|l|c|c|}
\hline Level of emotional intelligence & No of students (N=300) & Percentage of students \\
\hline Low level (50-117) & Nil & Nil \\
\hline Moderate level (118-184) & 102 & $34 \%$ \\
\hline High level (185-250) & 198 & $66 \%$ \\
\hline Total & 300 & $100 \%$ \\
\hline
\end{tabular}

\section{Interpretation}

The above table reveals the level of emotional intelligence of higher secondary students in and around Karaikudi.

$34 \%$ of students are having Moderate level of emotional intelligence, $66 \%$ of students are having high level of emotional intelligence. Hence the research hypothesis is accepted.

\section{Hypothesis :2}

There exists significant difference between the mean scores of emotional intelligence of higher secondary school students in relation to gender.

In order to find out the significance of difference between the mean scores of emotional intelligence of higher secondary school students in relation to gender, ' $\mathbf{t}$ ' test has been employed by the researcher and result is given in the following table. 
Table 2 Comparison of Mean and Standard Deviation values of emotional intelligence in relation to gender

\begin{tabular}{|l|c|c|c|c|c|}
\hline Gender & N & Mean & S.D & 't' value & Level of significance \\
\hline Male & 150 & 187.19 & 31.35 & 4.26 & $\begin{array}{l}\text { Significant at } 0.01 \text { and } \\
0.05 \text { level }\end{array}$ \\
\cline { 1 - 4 } Female & 150 & 200.19 & 20.23 & & \\
\hline
\end{tabular}

$D f=298$

\section{Interpretation}

From the table, it is inferred that the calculated ' $t$ ' value (4.26) is greater than the table value (2.59) at 0.01 level of significance. Hence there exists significant difference between the mean scores of emotional intelligence of higher secondary school students with respect to gender. Hence the research hypothesis is accepted.

\section{Hypothesis : 3}

There exists significant difference between the mean scores of emotional intelligence of higher secondary students with respect to the location of the schools.

In order to find out the significance of difference between the mean scores of emotional intelligence of higher secondary school students in relation to location of the school, ' $t$ ' test has been employed by the researcher and result is given in the following table.

Table 3. of Mean and Standard Deviation values of emotional intelligence in relation to location of the schools

\begin{tabular}{|l|c|c|c|c|c|}
\hline $\begin{array}{c}\text { Location of the } \\
\text { school }\end{array}$ & N & Mean & S.D & 't' value & Level of significance \\
\hline Urban & 140 & 191.17 & 26.77 & \multirow{2}{*}{2.25} & $\begin{array}{c}\text { Significant at } \\
0.05 \text { level }\end{array}$ \\
\hline Rural & 160 & 188.7 & 9.77 & & \\
\hline
\end{tabular}

$D f=298$

\section{Interpretation}

The calculated ' $t$ ' value (2.25) is greater than the table value (1.97) at 0.05 level of significance. Hence there exists significant difference between the mean scores of emotional intelligence of higher secondary school students with respect to location of the schools. Hence the research hypothesis is accepted.

\section{Hypothesis : 4}

There exists significant difference between the mean scores of emotional intelligence of higher secondary students with respect to the location of the students.

In order to find out the significance of difference between the mean scores of emotional intelligence of higher secondary school students in relation to location of the students, ' $\mathbf{t}$ ' test has been employed by the researcher and result is given in the following table. 
A Study on Emotional Intelligence of Higher Secondary Students in Karaikudi

Table 4. Comparison of Mean and Standard Deviation values of emotional intelligence in relation to Residence of the students

\begin{tabular}{|c|c|c|c|c|c|}
\hline $\begin{array}{c}\text { Residence of the } \\
\text { students }\end{array}$ & N & Mean & S.D & 't' value & Level of significance \\
\hline Urban & 176 & 179.57 & 35.04 & \multirow{2}{*}{6.93} & $\begin{array}{c}\text { Significant at } 0.01 \\
\text { and } 0.05 \text { level }\end{array}$ \\
\hline Rural & 124 & 214.61 & 53.74 & \\
\hline
\end{tabular}

$D f=298$

\section{Interpretation}

From the table, we come to know that the calculated ' $t$ ' value (6.93) is greater than the table value (2.59) at 0.01 level of significance. Hence these significant difference between the mean scores of emotional intelligence of higher secondary school students with respect to location of the students. Hence the research hypothesis is accepted.

\section{Hypothesis : 5}

There exists significant difference between the mean scores of emotional intelligence of higher secondary students with respect to management of the schools.

In order to find out the significance of difference between the mean scores of emotional intelligence of higher secondary school students in relation to management of the schools, ' $t$ ' test has been employed by the researcher and result is given in the following table.

Table 5. Comparison of Mean and Standard Deviation values of emotional intelligence in relation to Management of the Schools

\begin{tabular}{|c|c|c|c|c|c|}
\hline $\begin{array}{l}\text { Management of } \\
\text { the schools }\end{array}$ & $\mathbf{N}$ & Mean & S.D & ' $t$ ' value & $\begin{array}{c}\text { Level of } \\
\text { Significance }\end{array}$ \\
\hline $\begin{array}{l}\text { Government vs } \\
\text { Aided }\end{array}$ & 200 & $\begin{array}{l}162.96 \\
188.37\end{array}$ & $\begin{array}{l}90.35 \\
50.84\end{array}$ & 2.45 & $\begin{array}{c}\text { Significant at } 0.05 \\
\text { Level }\end{array}$ \\
\hline Aided vs Private & 200 & $\begin{array}{r}188.37 \\
191.24\end{array}$ & $\begin{array}{l}50.84 \\
11.96 \\
\end{array}$ & 0.55 & Not Significant \\
\hline $\begin{array}{l}\text { Private vs } \\
\text { Government }\end{array}$ & 200 & $\begin{array}{l}162.96 \\
191.24\end{array}$ & $\begin{array}{l}90.35 \\
11.96\end{array}$ & 3.10 & $\begin{array}{l}\text { Significant at } 0.01 \\
\text { and } 0.05 \text { level }\end{array}$ \\
\hline
\end{tabular}

\section{Interpretation}

From the above table, in the first comparison, the calculated ' $t$ '- value (2.45) is greater than the table value (1.97). Significant difference is found on the mean scores of emotional intelligence of higher secondary school students studying in government and government aided of schools.

In the second comparison, no significant difference is found between the mean scores of emotional intelligence of higher secondary school students studying in aided and private schools.

In the third comparison, the calculated ' $t$ '-value (3.10) is greater than the table value (2.59). Significant difference is found in the mean scores of emotional intelligence of higher secondary 
school students studying in private and government schools. Hence the research hypothesis is partially accepted.

\section{Hypothesis : 6}

There exists no significant difference between the mean scores of emotional intelligence of higher secondary students with respect to nature of the schools.

In order to find out the significance of difference between the Mean scores of emotional intelligence of higher secondary school students in relation to Nature of the schools, 't' test has been employed by the researcher and result is given in the following table.

Table 6. Comparison of Mean and Standard Deviation values of emotional intelligence in relation to Nature of the Schools

\begin{tabular}{|c|c|c|c|c|c|}
\hline $\begin{array}{l}\text { Nature of } \\
\text { the schools }\end{array}$ & $\mathbf{N}$ & Mean & S.D & ' $t$ ' value & $\begin{array}{c}\text { Level of } \\
\text { Significance }\end{array}$ \\
\hline $\begin{array}{c}\text { Co-education vs } \\
\text { Boys }\end{array}$ & 290 & $\begin{array}{l}188.48 \\
202.9 \\
\end{array}$ & $\begin{array}{r}128.16 \\
14.54 \\
\end{array}$ & 1.61 & Not Significant \\
\hline Boys vs Girls & 20 & $\begin{array}{l}202.9 \\
201.4 \\
\end{array}$ & $\begin{array}{r}14.54 \\
12.28 \\
\end{array}$ & 0.25 & Not Significant \\
\hline $\begin{array}{l}\text { Co-education vs } \\
\text { Girls }\end{array}$ & 20 & $\begin{array}{r}201.4 \\
188.48 \\
\end{array}$ & $\begin{array}{r}12.28 \\
128.16 \\
\end{array}$ & 1.5 & Not Significant \\
\hline
\end{tabular}

\section{Interpretation}

In the above table, the researcher has compared the mean values of the emotional intelligence of students studying in different schools. From the table, there exists no significant difference between co-education and boys schools as the ' $t$ ' value (1.61) is less than the table value(1.97). Similarly no significant difference is found between boys and girls school and co-education school and girls schools as their ' $t$ ' values are 0.25 and 1.50 respectively. Hence the research hypothesis is accepted.

\section{Hypothesis : 7}

There exists significant difference between the over-all scores of emotional intelligence of higher secondary students with respect to Parent's Occupation.

To test the above hypothesis ' $F$ '-test has calculated and the results are shown in the following table. 
Table 7 Significant difference between the Over-all scores of emotional intelligence of higher secondary students with respect to Parent's Occupation.

\begin{tabular}{|l|c|c|c|c|c|}
\hline \multicolumn{1}{|c|}{ Sources } & Df & $\begin{array}{c}\text { Sum of } \\
\text { Squares }\end{array}$ & $\begin{array}{c}\text { Mean sum of } \\
\text { squares }\end{array}$ & F-ratio & $\begin{array}{c}\text { Level of } \\
\text { Significance }\end{array}$ \\
\hline Between group & 3 & 2138411.5 & 712803.83 & & \\
\cline { 1 - 4 } $\begin{array}{l}\text { Within the } \\
\text { group }\end{array}$ & 296 & 1032743.5 & 3488.9983 & \multirow{2}{*}{204.30} & $\begin{array}{c}\text { Significant at } \\
0.01 \text { level }\end{array}$ \\
\hline Total & 299 & & & & \\
\hline
\end{tabular}

\section{Interpretation}

As the calculated ' $F$ ' value (204.30) is found significant between mean scores of emotional intelligence with respect to their Parent's Occupation. Hence the research hypothesis is accepted.

\section{MAJOR FINDINGS}

- The higher secondary students have high level of emotional intelligence.

- There exists significant difference between the mean scores of emotional intelligence of higher secondary school students in relation to gender.

- There exists significant difference between the mean scores of emotional intelligence of higher secondary students with respect to the location of the schools.

- There exists significant difference between the mean scores of emotional intelligence of higher secondary students with respect to the location of the students.

- There exists significant difference between the mean scores of emotional intelligence of higher secondary students with respect to management of the schools.

- There exists significant difference between the mean scores of emotional intelligence of higher secondary students with respect to nature of the schools.

- There exists significant difference between the over-all scores of emotional intelligence of higher secondary students with respect to Parent's Occupation.

\section{CONCLUSION}

Even though there are some limitations in the present study, it is evident that the emotional intelligence of the higher secondary students is high. The former president of India Dr. A.P.J. Abdul kalam expresses his faith in youths who would contribute the national development.

The recommendations given by the investigator may be very helpful for improving the emotional intelligence of higher secondary students. This study will be more fruitful when suggestions given by the investigator are applied for further study and it will be of a great help for those who want to study further in this field.

\section{REFERENCES}

[1] DANIEL GOLEMAN (1996), "Emotional Intelligence; Why it matter more than IQ Bloomsburg publications Great Britain.

[2] Emotional Intelligence among high school students - T.Subhas Chandra. Thoughts on Education, Vol III No.1. 
[3] GOLEMAN.D. (1996). Emotional Intelligence. Why it matters more than IQ learning, 24(6) pg 49-50.

[4] ROBERT COOPER AND AYMAN SAWAF (1997), 'Emotional Intelligence in BusinessExcellence IQ' Orion business books, Butler \& Tanner Ltd London.

[5] Role of Emotional Intelligence for Academic Achievement for students - Bhadouria Preeti, Research Journal of Educational Sciences ISSN 2321-0508 Vol. 1(2), 8-12 May (2013).

[6] SALOVEY AND MAYER (1990), Emotional Intelligence: Imagination, Cognition and Personality. 